\title{
The Influence of Contemporary Thinkers on Said's Orientalism
}

Mohammad Hossein Abedi Valoojerdi (Corresponding author)

University of Perpetual Help System DALTA, Philippines

Email: hossein.abedi@perpetualdalta.edu.ph

Received: $22 / 08 / 2020$

Accepted: 11/10/2020

Published: 01/11/2020

Volume: 1 Issue: 4

How to cite this paper: Abedi Valoojerdi, M. H. (2020). The Influence of Contemporary Thinkers on Said's Orientalism. Journal of Critical Studies in Language and Literature, 1(4), 41-46

DOI: https://doi.org/10.46809/jcsll.v1i4.41

Copyright (C) 2020 by author(s) and Global Talent Academy Ltd. This work is licensed under the Creative Commons Attribution International License (CC BY 4.0).

http://creativecommons.org/licenses/by/4.0/

$$
\text { (c) (G) }
$$

\begin{abstract}
Orientalism (1978) is one of the greatest intellectual works of the last century in which Edward W. Said (1935-2003) challenges Western culture on account of its erroneous beliefs about the East. Orientalism, as Said describes, is not merely an academic field of study, but a way of thinking and a collection of beliefs which work together as a powerful tool to justify the colonial ideology. However, what Said suggests is not an anti-Western theory. In Orientalism, he interacts with a number of his contemporary intellectuals. This paper is a brief review of the influence of contemporary philosophers, thinkers and Western theories on Said's interpretation of Orientalism. The paper also attempts to discuss that how Said's Orientalism is related to the above-mentioned theories such as Gramsci's cultural hegemony, Foucault's notion of power/knowledge, Derrida's deconstruction, and Bakhtin's polyphony. Although this topic has been of interest to other researchers, further studies will contribute to the richness of the subject and can be used by students and scholars.
\end{abstract}

Keywords: Postcolonial Theory, Orientalism, Other, Binary System, Deconstruction

\section{Introduction}

Edward William Said (1 November 1935 - 25 September 2003) has had a great influence on humanities, in general, and postcolonial studies, in particular. As Said applied various theories in his notion of Orientalism, he experienced the presence of different cultures in his life, too. He was born in Mandatory Palestine; a geopolitical entity in the territories of Palestine resulted from the partition of the Ottoman Empire after the First World War. Political conflicts over his homeland affected his entire life and he encountered identity problems from his childhood and adolescence. His mother was an Arab Christian while his father was a Palestinian who soldiered in the U.S. Army. He grew up in a community of Muslims and Jews, and attended St. George's School in East Jerusalem; then he attended Victoria College, Alexandria by the late 1940s. Said in his book: Between Worlds, Reflections on Exile and Other Essays (2000) explains how he was uncertain about his identity:

With an unexceptionally Arab family name like "Said", connected to an improbably British first name (my mother much admired Edward VIII the Prince of Wales in 1935, the year of my birth) I was an uncomfortably anomalous student all through my early years: a Palestinian going to school in Egypt, with an English first name, an American passport, and no certain identity, at all. To make matters worse, Arabic, my native language, and English, my school language, were inextricably mixed: I have never known which one was my first language, and have felt fully at home in neither, although I dream in both. Every time I speak an English sentence, I find myself echoing it in Arabic, and 
vice versa. (pp. 556-7)

In 1951, Victoria College expelled Said and he moved to the U.S. at the age of sixteen, where he earned a Bachelor's degree at Princeton University (1957). He then attended Harvard University and earned his Ph.D. degree in English Literature (1964). In the U.S., Said theorized the difference between the West and the East. He used Joseph Conrad's Heart of Darkness to describe the perplexity of someone who fluctuates between the two worlds. In his article Between Worlds: a memoir (1998), Said wrote: "I used Conrad as an example of someone whose life and work seemed to typify the fate of the wanderer who becomes an accomplished writer in an acquired language, but can never shake off his sense of alienation from his new - that is, acquired - and, in Conrad's rather special case, admired home." (para. 1)

Said coined the word 'Orientalism' which has become a crucial concept in Postcolonial Studies. It refers to the discourse applied by Western orientalists to create a manipulated desired image of the East, on the one hand, and a superior image of the West, on the other hand. Said argues that European scholars deliberately reproduce false images to promote the Eurocentrist worldview, part of which presents the East as exotic, uncivilized, and in many cases dangerous.

This paper argues that what Said depicts in his book Orientalism, although it looks anti-Western in appearance, he has applied extensive use of Western logic and philosophy in his way of reasoning.

The importance of Said's work, Orientalism (1978), can be studied in two areas: First, its mediation of French modes of analysis into the Anglo-American academic world. Moore-Gilbert (1997) is of the opinion that Orientalism "provided one of the first examples of a sustained application of such modes of analysis to Anglophone cultural history and textual tradition." (p.33)

Second, Said in Orientalism paved a way to show the links between politics and culture, and to explain how Western culture functions as a justifier of colonial behaviors. He argues that European scholars and writers deliberately fabricated false images of the East and helped to normalize the unpleasant actions of the colonialists. They spread the Eurocentrism worldview: the East always is exotic, uncivilized, and in many cases dangerous. .

Although Said's theory seems anti-Western, the purpose of this paper is to illustrate the impact of Western theories on the formation of Said's Orientalism.

\section{European Analysis and the Concept of the Other}

Perhaps the critique of Saussure's binary system can be defined as the starting point for Said's Orientalism, particularly in shaping the concept of others. Ferdinand de Saussure (1857-1913), in his lectures in Geneva, claimed that the units of language have value or meaning and "each unit is defined against what it is not". (Fogarty, 2005) However, Said was not the first to criticize the Saussure's binary system. Jacques Derrida (1930-2004) for the first time, as Lawlor (2019) points out, explained about the term 'deconstruction' in an interview: Positions (1971), and in his book: Dissemination (1972).

"In a classical philosophical opposition," Derrida specifies, "we are not dealing with the peaceful coexistence of a vis-avis, but rather with a violent hierarchy. One of the two terms governs the other (axiologically, logically, etc.), or has the upper hand." (1981, p.41) Derrida criticizes Hegel's dialectical speculation and suggests, as the first measure of deconstruction we should overturn the hierarchical system.

Said used the idea of classical oppositions and located the Western perspective of the East in the frame of a binary system, Then, simultaneously, by using Derrida's deconstruction he uncloaked the distorted image of the East as the world of wonders that needs to be governed by colonial powers.

Said also, by scrutinizing the hierarchical system in which the West has the upper hand, claimed that Europeans are trying to shape their identities in opposition to the inferior other. He believed that the binary opposition of West/East is a discourse of inequality, created in order to hyperbolize the differences between the East and the West.

Consequently, Said employed the Foucauldian discourse of knowledge that focuses, according to Foucault, on creating "a history of the different modes" by which "human beings are made subjects." (2000, p. 326)

In fact, subject is the central theme of Foucault's theory, and can be explained through modes of objectification which all work together to magnify the subject.

In order to study the process of objectification, we need to learn how concepts such as science, politics, and morality work in a society. The first mode, as Foucault explains (2000), is the mode of inquiry in objectivizing the productive subject through measurement and examination; for example, objectivizing of the speaking subject in grammar generally, philology, and linguistics.

The second mode is objectivizing the subject or "dividing practices," and during this process, the subject is divided within itself or segregated from others; like 'the mad and the sane' or 'criminals and good boys.'

Through the third mode, a human being turns himself or herself into a subject; like the domain of sexuality, and the fact that "how men have learned to recognize themselves as subjects of "sexuality." (Pp. 326-27)

These modes, as Katz (1996) asserts, represent classification practices, dividing practices, and self-objectification practices. They operate as an axis which structures the subjectivity under the host of modernity. (p. 17)

Along with the subject and power, history is another key concept in Foucault's notion. In fact, 'history' in Foucault's discourse is a 'genealogy' or "a form of history that can account for the constitution of knowledge, discourses, and domains of objects" (Foucault, In Down 1994). 
Said argued that the concept of the Orient is not about a real geographical range, nor matches the facts about the East; instead, this way of thinking is the result of a strong desire to show differences, and it provides the ground for domination. Said employed the modes of objectification in order to clarify the concept of 'the Other.' As he emphasizes, European orientalists divide human existence into two opposite poles: the Western human and the Eastern human or the Western culture and the Eastern culture; and always the East is playing the role of the Other.

Although, the original publication of The Subject and Power by Foucault was in 1982 and Orientalism was published in 1978, yet the influence of Foucault is undeniable. The Subject and Power was a conclusion of Foucault's previous works such as Madness and Civilization: A History of Insanity in the Age of Reason (1961), The Birth of the Clinic: An Archaeology of Medical Perception (1963), The Order of Things: An Archaeology of the Human Sciences (1966), The Archaeology of Knowledge (1969), Discipline and Punish: The Birth of the Prison (1975), and The History of Sexuality (1976). In fact, Said has applied the resultant of all the works mentioned above, and his idea about the Orientalism is a reflection of Foucault's notion of history and archaeology.

Said has also benefited from Egyptian scholar Abdel Malek's Orientalism in Crisis (1963), specifically regarding the concept of Other which is coined by Said. According to Anwar Abdel Malek (1924-2012), the traditional orientalism imposes a type of cognition which is predicated on racial and ethnic specifications such as language as an inevitable result of such an attitude:

We will have a homo Sinicus, a homo Arabicus (and why not a homo Aegypticus, etc.), a homo Africanus, the man- the "normal man," it is understood-being the European man of the historical period, that is, since Greek antiquity. One sees how much, from the eighteenth to the twentieth century, the hegemonism of posses-sing minorities, unveiled by Marx and Engels, and the anthropocentrism dismantled by Freud are accompanied by eurocentrism in the area of human and social sciences, and more particularly in those indirect relationships with non-European peoples. (1963, pp. 107-8)

Orientalism, as portrayed by Said, has two different meanings; one is academic and the other is imaginative. However, both work together as an intertwined network of historical, political, social, and cultural relations to institute distinction between the West and the East. The third meaning of Orientalism, as Said specifies, is "a Western style for dominating, restructuring, and having authority over the Orient." (1978, p.3)

Said applies the Gramsci's ideas about hegemony and personal inventory as well. Cultural hegemony refers to the ideological and cultural domination by a particular group of people and, according to Gramsci, is a product of the interconnected relationships of language, culture, society, and social institutions.

Gramsci believed that culture and language are political issues. He tried to disclose how the political power takes advantage of the metaphorical power of the language, in order to dominate the people subtly.

Cultural hegemony is most strongly manifested when those ruled by the dominant group come to believe that the economic and social conditions of their society are natural and inevitable, rather than created by people with a vested interest in particular social, economic, and political orders. (Cole, 2017)

Although Said applies Foucault and Gramsci's ideas, as Ghazoul writes, the applying of these ideas is more strategic than indicating membership in their school of thought. (2007, p.47)

Said, of course, acknowledges that the Foucault's discourse is the main ground of his Orientalism. However, he tries to make a distinction between himself and other thinkers such as Foucault or Gramsci at the same time:

"Yet unlike Michel Foucault, to whose work I am greatly indebted, I do believe in the determining imprint of individual writers upon the otherwise anonymous collective body of texts constituting a discursive formation like Orientalism." (1978, p.23)

\section{Said's Culture and Imperialism}

Said, later, expanded his theory of Orientalism, in Culture and Imperialism (1993), and criticized the cultural politics of European colonizers through re-reading the prominent novels of influential literary figures such as Jane Austen and Rudyard Kipling.

Contrary to Orientalism, that had more theories to offer, Said steps into the field of literary criticism in Culture and Imperialism. He employs a new method of analysis to interpret some literary texts as the works that provided grounds for colonial discourse. In this contrapuntal method or analysis, Said was inspired by the concept of counterpoint in music. As a contrapuntal music deals with the handling of two melodic lines played simultaneously, Said tried to discover and show the hidden melodic line of the selected novels.

We can match the melodic lines in music with storylines in a novel. While one storyline is the manifest narrative of the story, there are other historical narratives hidden between the lines of the story. Said believed that the power to narrate or block other narratives from forming and emerging is significant and constitutes one of the main connections between culture and empire. (1993, P. xiii) In fact, contrapuntal reading helps Said to uncloak the links between the story and the relevant repressed narratives of history. A contrapuntal approach discovers the connections between conflicting experiences, such as "coronation rituals in England and the Indian durbars of the late nineteenth century," as Said writes. (1993, p.36)

A particularly good example of the value of a contrapuntal perspective is the contradictory place of Kipling's picture of India in Kim in the development of the English novel on the one hand, and the development of Indian independence on the 
other hand. ... contrapuntal reading does not simply exist as a form of refutation or contestation, but as a way of showing the dense interrelationship of imperial and colonial societies." (Ashcroft and Alhuwalia, 2001, p.94)

In a contrapuntal reading of a novel, both colonial and colonized perspectives will be examined. It is not just a typical reading of a novel, but it is a journey to the hidden parts of history. It reveals facts about the colonizers and what they have done to suppress the indigenous people. "Either the novel or the political movement represented or interpreted without the other misses the crucial discrepancy between the two given to them by the actual experience of empire." (1993, p.36)

In Jane Austen's Mansfield Park, when Sir Thomas Bertram is in the Caribbean sugar plantation, we never read anything about the wrongdoing that has been inflicted on the people in that slave-run estate. The main task in a contrapuntal reading is to discover and narrate this unspoken story and Said applies this method to support his notion about the relations between the European novel and Imperialism. In Heart of Darkness, for instance, Conrad encapsulates two different 'but intimately related aspects of imperialism,' claims Said; the idea of using the power to capture territories, and 'the practice that essentially disguises' the consequences of the use of force against the inhabitants of the occupied territories 'by developing a justificatory regime of self-aggrandizing, self-originating authority interposed between the victim of imperialism and its perpetrator.'

Said argues that the imperial culture has been legitimized through these literary works. It might be a true conclusion of Said's book, Culture and Imperialism, that the European novel has played an extensive role to justify Imperialism, and this role is one of the functions of the novel as a genre. However, when Said (1993) indicates that without empire, "there is no European novel as we know it," (p. 82) it seems that he ignores the evolution of the novel throughout history. For example, he forgets the role of pre-genres such as Novella and works such as Boccaccio by Decameron in shaping the novel.

Said, however, does not tend to either condemn or ignore the authors, and "their participation in what was an unquestioned reality in their societies." Instead, he suggests that: "what we learn about this hitherto ignored aspect actually and truly enhances our reading and understanding of them." (1993, p. xiv.)

\section{Said and Raymond Williams}

As discussed earlier, Said has been influenced by the works of many thinkers such as Foucault, Derrida, Anwar Abdel Malek, and Gramsci. Michael Gorra (1993) points out to the title of Edward W. Said's Culture and Imperialism, which deliberately echoes the titles of two great works of criticism: Matthew Arnold's Culture and Anarchy (1869) and Culture and Society 1780-1950 (1958) by Raymond Williams. According to Garnier, Said's claim "in Culture and Imperialism --that the West justified its imperial domination over the rest of the world by overvaluing its own culture-owes much to the work of Raymond Williams, the founder of the field of cultural studies." (2014, p.41)

Raymond Williams (1921-1988) was a Professor of Drama (1974-1983) in Cambridge. However, he is known as one of the most influential socialist thinkers in the world. His works cover a wide range of Humanities. After his death, Said in The Nation obituary wrote:

To trans-Atlantic readers, the long list of Williams' work has always seemed astounding. Here was a Cambridge Professor of Drama who not only wrote about the entire range of English literature but who established cultural studies at the Pinnacle of humanistic research, film, critical theory, television society and history with prescient authority, and was polemically involved as an unwavering man of the left and artistically involved with literature as novelist. (1988, p.314) 1950 .

In fact, 'culture' in its transformed sense is Williams' primary concern, especially, in his book Culture and Society1780-

According to K. W. Christopher (2013), "Williams' early work carries the Cambridge English emphasis on 'close reading' and is solely concerned with intense literary analysis. But since the publication of Culture and Society Williams has been moving away from close reading of literary texts to the study of a wider field which he called culture."

The title of Williams's best-known essay, itself, is the best description of his idea about the 'culture': Culture is Ordinary (1958). This title as a sentence provides the basis of his thinking about culture. Williams believed that culture is not exclusive to the elite class; rather it is a public matter. He claims that all cultures have two aspects: 'known meanings and directions,' and 'new meanings and observations.'

Williams, in Culture and Society: 1780-1950, explained his idea of changing the meaning of words over time. He chose five words to explain their new meanings at the first step: industry, democracy, class, art, and culture. Williams believed that there is a general pattern of change in these words, "and this can be used as a special kind of map by which it is possible to look again at those wider changes in life and thought to which the changes in language evidently refer." The historical formation of the word 'culture' is "a record of a number of important and continuing reactions to these changes in our social, economic and political life.” (1960, P.XI)

Said's contrapuntal reading is actually a technique to find the relations between texts or novels and the 'culture' in which such novels are shaped. Since culture embraces all aspects of human life, in reading a novel, we cannot be indifferent to its political, ideological, and social aspects. As Williams (1989) writes in Culture is Ordinary, "a culture must finally be interpreted in relation to its underlying system of production." (p. 7) 


\section{Said and Bakhtin}

Many essays have reflected the influence of Western thinkers on Said's postcolonial theory. However, little attention has been paid to the influence of Mikhail Mikhailovich Bakhtin (1895-1975) and Bakhtinian theories of polyphony, dialogue, and intertextuality on Said's works. There is a fine line between Said's contrapuntal reading and Bakhtinian polyphony. The nature of contrapuntal reading is based on 'dialogue.' Bakhtin examined the concept of 'dialogue' as a subject to study literary structure. He believed that "literary structure does not simply exist but is generated in relation to another structure." (Kristeva, 1986, p. 35) Bakhtin, as stated by Svoboda (2005), "constructed a literary theory based on dialogue and as a part of his theoretical work." (p. 109)

Bakhtin's seminal work Problems of Dostoevsky's Poetics was first published in Russia as Problems of Dostoevsky's Art in 1929. He republished his book, with many revisions and additions, after 34 years in 1963 in Moscow. The first English translation of the book was published in 1973 by R. William Rotsel, and in France Julia Kristeva (born 24 June 1941) introduced Bakhtin to French readers in her article le mot, le dialogue et le roman (1967).

Bakhtin, in his book, applied polyphony to refer to the simultaneity of discourses, voices, and points of view in Dostoevsky's novels. According to Allen (2006), it is “a term which dominates much of Bakhtin's analysis of the novels of Dostoevsky, who for Bakhtin represents the apotheosis of dialogic literary creation.”(p.22)

Bakhtin was of the opinion that Dostoevsky in his novels establishes dialogic relationships among characters, "in all manifestations of conscious and intelligent human life." (1984, p. 40)

Contrapuntal reading, as applied by Said, is a dialogic relationship through discourse variation, too. Interestingly, both terms (polyphony and contrapuntal) are derived from music and have a similar nature. As Said clarifies, contrapuntal reading necessitates "awareness both of the metropolitan history that is narrated and of those other histories against which (and together with which) the dominating discourse acts." (1993, p.51)

\section{Conclusion}

Edward Said in his book Orientalism delves into the stereotypes employed by Western scholars to describe the colonized countries as exotic and uncivilized. He argues that the Western discourse as an intertwined network of colonial economics and politics, accompanied by cultural elements such as literature, deliberately conceal the violence associated with colonial practices. Wars and bloodshed are often absent in the colonial discourse. However, in his attempt to explain this phenomenon, Said has made great use of the theories formed in Western culture.

This paper discussed the widespread presence of these theories in the heart of Said's notion of Orientalism. It explained Derrida's critique of Saussure's binary system, known as deconstruction, as the starting point of Said's theory. The concept of the "Other" coined by Said, that reflects the idea that one group can marginalize another group and distinguishes itself, owes much to the theories of Foucault and Derrida. The paper also argued that Said applied the Gramsci's theory of hegemony and personal inventory to manifest the 'cultural hegemony' of Western culture and disclose how political power takes advantage of the language to dominate the people subtly.

\section{References}

Abdel Malek, A. (1963). Orientalism in Crisis. In Diogenes, 44 (Winter), 107-108

Allen, G. (2006). Intertextuality. London: Routledge

Ashcroft, B and P. Ahluwalia. (2001). Edward Said. NY: Routledge

Bakhtin, M.M. (1984). Problems of Dostoevsky's Poetics. Minnesota: University of Minnesota Press

Christopher, K. W. (2013). Raymond Williams and Marxist Literary Theory. The Criterion. 4(V). Retrieved from http://www.the-criterion.com/V4/n5/Christopher.pdf

Cole, N. L. (2017). Definition of Cultural Hegemony. In Thoughtco. Retrieved From https://www.thoughtco.com/culturalhegemony-3026121

Down, B. (1994). Marxist history and schooling: Beyond economism. In Issues in Educational Research, 4(1), 1-17. http://www.iier.org.au/iier4/down.html

Derrida, J. (1981). Positions. London: The Athlone Press

Fogarty, S. (2005). The literary Encyclopedia, Retrieved from http://www.litencyc.com/php/stopics.php?pec=true\&UID=122 Foucault, M. (1977). Discipline and Punish: The birth of the prison. London: Penguin.

Foucault, M. (1982). The Subject and Power. Critical Inquiry, 8(4), 777-795

Foucault, M. (1985). Truth, power, and sexuality. In V. Beechey \& J. Donald, (Eds.), Subjectivity and social relations. Philadelphia: Open University Press.

Foucault, M. (2000). Power. In Faubion, J. D. (Ed.). NY: The New Press

Garnier, X. (2014). Edward W. Said et Raymond Williams: débat sur la culture impériale. Sociétés \& Représentations, 37,(1), 41-51. https://www.cairn.info/revue-societes-et-representations-2014-1-page-41.htm.

Ghazoul, F J.( 2007). Edward Said and Critical Decolonization. Cairo: The American University in Cairo Press 
Gorra, M. (1993). Who Paid the Bills at Mansfield Park?. The New York Times. Retrieved from: https:// archive.nytimes.com/ www. nytimes.com/ books /99/10/03/ specials/said-culture.html

Katz, S. (1996). Disciplining Old Age: The Formation of Gerontological Knowledge. Charlottesville: University Press of Virginia

Kristeva J. (1967). le mot, le dialogue et le roman // Critique. April. 438-465

Kristeva, J. (1967). Word, dialogue and novel. In M. Toril (ed.) . The Kristeva Reader. NY: Columbia University Press

Kristeva, J. (1986). The Kristeva Reader.Ed: Toril,M. NY: Columbia University Press

Lawlor, L. (2019). Jacques Derrida, In E. N. Zalta (Ed.), The Stanford Encyclopedia of Philosophy. Stanford: Metaphysics Research Lab.https://plato.stanford.edu/archives/fall2019/entries/derrida/>

Moore-Gilbert, B. (1997). Postcolonial Theory: Contexts, Practices, Politics. NY: Verso

Said, E. (2000). Between Worlds, Reflections on Exile and Other Essays. Cambridge: Harvard University Press

Said, E. (1998). Between Worlds: a memoir. In London Review of Books, 20(9)

Said, E. (1993). Culture and Imperialism. London: Chatto \&Windus

Said, E. (1978). Orientalism. NY: Vintage

Svoboda, M. (2005, Spring). Rhetoric Society Quarterly, 35(2), 109-112

Williams, R. (1960). Culture and Society 1780-1950. NY: Anchor Books

Williams, R. (1989). Culture is Ordinary. In Resources of Hope: Culture, Democracy, Socialism. (pp. 3-14). London: Verso 